Jurnal Keuangan dan Perbankan, Vol.19, No.3 September 2015, hlm. 391-399

Terakreditasi SK. No. 040/P/2014

http://jurkubank.wordpress.com

\title{
DAM PAK STRUKTUR KEPEMILIKAN, FINANCIAL LEVERAGE, BOARD DIRECTOR TERHADAP NILAI PERUSAHAAN
}

\author{
Sri Dwi Ari Ambarwati \\ Rini Dwi Astuti \\ Fakultas Ekonomi UPN “Veteran” Yogyakarta
}

\begin{abstract}
This study tried to analyzetheeffect of ownership structure, financial leverage, size of board directors and sales Growth on the performance of companies with lower growth opportunities, whether there is a proxy growth opportunities with low PER. This research was conducted at themanufacturing company with the selection criteria for purposive sampling method 2010-2012 period, based on the criteria the obtained sample of 32 companies with low growth opportunities. Thus obtained 96 obervasi for each group. Theresults showed that: 1). simultaneously the ownership structure, financial leverage, size of board directors and sales G rowth affect the performance of companies with low growth opportunities. 2). Partially, it was found empirical evidence that financial leverageand variable size of board directors significantly affect thecompany's performance with lower growth opportunities. For institutional ownership structurereveal ed a significant effect on performance, but at a rate of $10 \%$ al pha tolerated.
\end{abstract}

Keyw ord: 0 wnership structure, leverage, size of board, growth opportunities

Beberapa literatur mengungkapkan bahwa peluang pertumbuhan (growth opportunities) mempengaruhi hubungan antara nilai perusahaan/ kinerja dan keputusan keuangan perusahaan (Smith and Watts, 1992; Chen and Liu, 2010, Reyna \& Encalada, 2012). N amun tidak ditemukan bagaimana hubungan ini dipengaruhi oleh struktur kepemilikan, khususnya kepemilikan insider. Ini isu yang menarik karena konflik kepentingan yang baru akan muncul antara pemegang saham mino- ritas dan mayoritas. (Shleifer \& Vishny, 1997). La Porta,etal (2000) telah membuktikan bahwa di beberapa negara, Expropriation (kecurangan) yang dilakukan oleh para manajer dan pemegang saham pengendali (controlling shar eholder) terhadap para pemegang saham minoritas dan para keditor sangat besar. Pada saat para investor mendanai perusahaan, mereka menghadapi risiko dan kadang-kadang besar kemungkinannya bahwa kembalian atas investasi yang mereka tanamkan tidak pernah material,

Koresponden dengan Penulis

Sri Dwi Ari Ambarwati, Rini Dwi Astuti: Telp:

E-mail: ambarwati-73@yahoo.com, rinidwiastuti@upnyk.ac.id 


\section{Jurnal Keuangan dan Perbankan | KEUANGAN}

Vol. 19, N 0.3, September 2015: 391-399

karena para manajer dan pemegang saham pengendali melakukan ekspropriasi terhadap mereka.

Penelitian terkait dilakukan oleh Reyna \& Encalada (2012) pada perusahaan di M exicotentang pengaruh struktur kepemilikan, financial leverage dan proporsi direktur terhadap nilai perusahaan dengan membedakan ada tidaknya peluang pertumbuhan untuk sampel yang ditelitinya. Kepemilikan keluarga/ insider, komposisi dan ukuran direktur serta leverage keuangan memainkan dua peran yaitu bisa meningkatkan kinerja pada perusahaan yang tidak memiliki peluang pertumbuhan menguntungkan tapi sebaliknya, memiliki pengaruh negatif pada perusahaan yang memiliki peluang pertumbuhan. Masalah baru muncul antara pemegang saham mayoritas dan minoritas pada perusahaan dengan peluang pertumbuhan yang lebih tinggi. N amun demikian konsentrasi kepemilikan, hutang dan board director hanya sebuah mekanisme dalam perusahaan yang memiliki peluang pertumbuhan untuk meningkatkan nilai perusahaan dengan mengurangi adanyakonflik keagenan.

Hasil penelitian Ahmad, et.al (2012) pada perusahaan Malaysia menemukan bukti empiris bahwa struktur modal seperti hutang jangka pendek dan total hutang berpengaruh terhadap kinerja perusahaan. Hasil ini mendukung temuan Reyna \& Encalda (2012) dan membuktikan tulisan sebelumnya oleh Ross (1977), Heinkel (1982) and N oe (1988) yang menyatakan bahwa penambahan leverage dengan menambah hutang perusahaan memberikan implikasi postif bagi nilai perusahaan dan kinerja. Lebih jauh, hasil penelitian ini juga didukung oleh penelitian Hadlock\&James (2002) dimana mereka menyimpulkan bahwa perusahaan lebih menyukai hutang karena untuk mengantisipasi tingginya pembayaran pajak.

Urgensi atau alasan melakukan penelitian ini adalah munculnya fenomena konflik keagenan antara pemilik dan manajer serta kreditur yang masih tetap memberikan pengaruh terhadap kinerja perusahaan. Struktur kepemilikan baik kepe- milikan insider dan institusional dan keputusan pendanaan sangat mempengaruhi kinerja perusahaan yang mana pengaruh itu akan lebih untuk perusahaan yang memiliki peluang pertumbuhan lebih tinggi. Penelitian ini merupakan replikasi gabungan penelitian Reyna \&Encalada (2012), A bor (2005) dan Zurraidah A hmad,et.al (2012) dengan lebih menekankan pada pengaruh karakteristik perusahaan seperti struktur kepemilikan (insider dan institusi), leverage, sales growth dan sizeterhadap kinerja perusahaan dengan membedakan ada tidaknya peluang pertumbuhan (growth opportunities) yang dalam hal ini menggunakan proksi Price Earnings Ratio (PER) seperti yang dilakukan oleh Smith and Watts (1992), McConnell-Servaes, (1995), Kallapur (2001) dan Reyna \& Encalada, (2012)

\section{KAJIAN PUSTAKA}

Seiring perkembangan literatur manajemen keuangan menunjukkan bagaimana peluang pertumbuhan (growth opportunities) memberikan pengaruh pada hubungan kinerja/ nilai perusahaan dan keputusan keuangan perusahaan (struktur modal) (Smith and Watts, 1992; Chen and Liu, 2010; Reyna, 2012). Meski begitu beberapa penelitian belum menemukan bagaimana hubungan ini dipengaruhi struktur kepemilikan, khususnya (kepemilikan orang dalam (insider ownership) karenaisu baru muncul bahwa konflik keagenan lebih dipengaruhi oleh orang dalam (insider) hal itu disebabkan oleh adanya perbedaan perlakuan yang berbeda antara pemegang saham pengendali (misal:institutional) dan pemegang saham minoritas (misalnya: orang dalamatau individu) (ShleiferVishny,1997;La Porta et.al, 2000; Reyna-Encalada, 2012)

Pemisahan status antara pemilik dan pengeIola perusahaan menimbulkan suatu masal ah yang biasa disebut agency problems, terjadi antara pemilik perusahaan atau shareholders di satu sisi dengan 


\section{Dampak Struktur Kepemilikan, Financial Leverage, Board Director terhadap Nilai Perusahaan}

Sri Dwi Ari Ambarwati \& Rini Dwi Astuti

manajemen selaku pengelola di sisi lain. Posisi manajemen yang sangat dominan dalam suatu perusahaan membuat manajemen sering keluar dari batas yang ditentukan dan melupakan esensi keberadaan pihak manajemen, yaitu meningkatkan kesejahteraan pemilik perusahaan. $\mathrm{H}$ al ini menjadi kelemahan dalam agency theory, yakni karena keleluasaan manajemen perusahaan untuk memaksimal kan laba perusahaan yang bisa mengarah pada proses memaksimalkan kepentingan manajemen sendiri dengan beban dan biaya yang harus ditanggung oleh pemilik. Konflik keagenan untuk perusahaan-perusahaan publik di negara berkembang adalah disebabkan adanya konflik kepentingan antara pemegang saham pengendali (controIling shareholder) dan pemegang saham minoritas (minority shareholder) (Slheifer and Vishny, 1997). Masalah konflik keagenan akan lebih banyak terjadi di negara dengan proteksi investor rendah seperti di M exico (La Porta et.al, 1999)

Penelitian tentang teori struktur modal diawali oleh Miller dan Modigliani (1958) mereka menemukan bahwa nilai perusahaan (value of the firm) dipengaruhi oleh struktur modal perusahaan. Mereka juga menyimpulkan bahwa teori ketidakrelevanan struktur modal dimana financial leverage tidak mempengaruhi nilai perusahaan hanya pada kondisi pasar sempurna. M M menyatakan bahwa tanpa pajak maka struktur modal tidak mempengaruhi nilai perusahaan. Meskipun pendapat ini tidak konsisten dengan kondisi riil dimana perusahaan pasti memiliki kewajiban pajak sehingga teori ini masih menjadi perdebatan (Ahmad, A bdullah \& Roslan,2012)

Penelitian terkait dilakukan oleh Reyna \& Encalada (2012) pada perusahaan di Mexicotentang pengaruh struktur kepemilikan, financial leverage dan proporsi direktur terhadap nilai perusahaan dengan membedakan ada tidaknya peluang pertumbuhan untuk sampel yang ditelitinya. Kepemilikan keluarga/ insider, komposisi dan ukuran direktur serta leverage keuangan memainkan dua peran yaitu bisa meningkatkan kinerja jika tidak ada proyek investasi tapi memiliki pengaruh negatif jika ada peluang pertumbuhan. Masalah baru muncul antara pemegang saham mayoritas dan minoritas pada perusahaan dengan peluang pertumbuhan yang lebih tinggi. Namun demikian konsentrasi kepemilikan, hutang dan board director hanya sebuah mekanisme dalam perusahaan yang memiliki peluang pertumbuhan.

Hasil penelitian A hmad, et.al (2012) pada perusahaan Malaysia menemukan bukti empiris bahwa struktur modal seperti hutang jangka pendek dan total hutang berpengaruh terhadap kinerja perusahaan. Hasil ini mendukung temuan Reyna \& Encalda (2012) dan membuktikan tulisan sebelumnya oleh Ross (1977), Heinkel (1982) and N oe (1988) yang menyatakan bahwa penambahan leverage dengan menambah hutang perusahaan memberikan implikasi postif bagi nilai perusahaan dan kinerja. Lebih jauh, hasil penelitian ini juga didukung oleh penelitian Hadlock and James (2002) dalam Reyna \& Encalda (2012) dimana mereka menyimpulkan bahwa perusahaan lebih menyukai hutang karena untuk mengantisipasi pembayaran pajak yang lebih tinggi.

Gleason et.al (2000) menguji hubungan antara kinerja dan leverage dengan menggunakan proksi kinerja return on assets. Hasil penelitian adalah total hutang memiliki pengaruh negatif terhadap kinerja, kemudian dua implikasi dapat disimpulkan yaitu struktur modal memiliki pengaruh signifikan terhadap kinerja dan koefisien negatif menunjukkan secara umum penggunaan hutang yang lebih besar bagi perusahaan menyebabkan pengaruh negatif itu. Struktur modal juga tidak hanya merupakan penentu kinerja, ukuran (size) perusahaan juga merupakan penentu kinerja perusahaan yang lebih besar akan menghasilkan return on asset yang lebih besar pula dibanding perusahaan kecil. Hasil ini didukung oleh Agarwal, et.al (2001) ketika hutang memiliki pengaruh negatif terhadap profitabilitas. Namun profitabili- 


\section{Jurnal Keuangan dan Perbankan | KEUANGAN}

Vol. 19, N 0.3, September 2015: 391-399

tas perusahaan berhubungan positif dengan sales dan sales growth. Penelitian ini juga selaras dengan Hames and Chen (2004) dalam Reyna-Encalada (2012) dimana rasio hutang memiliki hubungan negatif dengan kinerja namun size memiliki hubungan positif terhadap kinerja.

Mesquita and Lara (2003) menemukan bukti empiris bahwa hutang jangka panjang tidak berpengaruh terhadap return on equity dan bertanda negatif, namun hutang jangka pendek memiliki tanda positif. Abbor (2005) melakukan penelitian di Ghana dan menemukan bukti bahwa hutang jangka pendek memiliki hubungan positif signifikan terhadap return on equity (ROE), dia menganggap bahwa hutang jangka pendek tidak mahal dalam meningkatkan keuntungan perusahaan. Hasil ini juga menyatakan bahwa profitabilitas mampu ditingkatkan dengan sales dan sales growth. Untuk hutang jangka panjang memiliki hubungan negatif signifikan dengan kinerja. A rtinya peningkatan dalam hutang jangka panjang berhubungan dengan pengurangan profitabilitas dan lebih mahal. Implikasinya adal ah posisi hutang berhubungan dengan peningkatan profitabilitas, rasio hutang yang tinggi akan meningkatkan profitabilitas. Selain itu terdapat hubungan positif antara ukuran perusahaan (size) dan sales growth.

Berdasarkan beberapa hasil riset sebel umnya maka dapat dirumuskan hipotesis sebagai berikut: $\mathrm{H}_{1}$ : Diduga terdapat pengaruh signifikan secara serempak struktur kepemilikan, financial leverage, size dan sales growth terhadap kinerja pada perusahaan dengan growth opportunities rendah.

$\mathrm{H}_{2}$ : Diduga terdapat pengaruh signifikan secara parsial struktur kepemilikan, financial leverage, size dan sales growth terhadap kinerja pada perusahaan dengan growth opportunities rendah.

\section{METODE PENELITIAN}

\section{Sampel Penelitian}

Penelitian ini dilakukan pada perusahaan manufaktur yang terdaftar di Bursa Efek Indonesia periode 2010 sampai 2012 yaitu ada 128 perusahaan, dan sampel yang memenuhi kriteria penelitian adalah 64 perusahaan (kemudian diranking menjadi dua kelompok yaitu 32 perusahaan dengan PER tinggi dan 32 perusahaan dengan PER rendah) selama 3 tahun sehingga jumlah observasi sebesar 96 observasi untuk perusahaan dengan PER Tinggi dan 96 untuk PER rendah. Pengumpulan data dilakukan dengan metodedokumentasi dari Indonesian Capital M arket Directory (ICMD) tahun 2010- 2012 dan dari ruang penelusuran UPN "Veteran" Yogyakarta. Analisis data dari model dengan dukungan program Eviews. Artikel ini khusus melihat dan menguji perusahaan dengan peluang pertumbuhan rendah karenaingin menguji apakah dampak struktur kepemilikan, financial leverage, size dan sales growth masih berpengaruh signifikan meskipun perusahaan tersebut tidak memiliki peluang investasi (underinvestment)

\section{Teknik Analisis Data Uji Regresi OLS}

Analisis estimasi data dari seluruh model persamaan regresi dalam penelitian ini dilakukan dengan bantuan program Eviews. Analisis dalam penelitian ini menggunakan persamaan regresi yang diformulasikan sebagai berikut:
$\mathrm{Q}_{\text {Low-PER }}=\alpha+\beta_{1}$ INSD $_{\text {it }}+\beta_{2}$ INST $_{\text {it }}+\beta_{3}$ LEV $_{\text {it }}+\beta_{4}$ $\mathrm{SIZE}_{\mathrm{it}}+\beta_{5} \mathrm{SG}_{\mathrm{it}}+\mathrm{e}_{\mathrm{it}} \ldots$ model 1

Keterangan:

Q = tobin's Q = Nilai perusahaan

INSD =kepemilikan insider/ internal

INST =kepemilikan institusi/ eksternal

LEV = financial leverage 


\section{Dampak Struktur Kepemilikan, Financial Leverage, Board Director terhadap Nilai Perusahaan \\ Sri Dwi Ari Ambarwati \& Rini D wi Astuti}

SIZE = ukuran board of director (outsider)

$\mathrm{SG}=$ sales growth

TA $=$ Total assets

e $=$ error term

\section{Uji Hipotesis}

Uji F digunakan untuk menguji model regresi atas pengaruh seluruh variabel bebas (independen) secara bersamaan terhadap variabel terikat (dependen) dan Uji tadalah uji parsial yang digunakan untuk menguji keterkaitan antara variabel bebas (independen) secara individual dengan variabel terikat (dependen).

\section{Uji Asumsi Klasik}

Untuk mendapatkan model regresi yang tidak bias atau BLUE maka perlu dilakukan uji asumsi klasik meliputi uji Multikolinearitas, Autokorelasi dan heterokedastisitas.

\section{ANALISIS HASIL Hasil Regresi OLS}

Berdasarkan olah data statistik eviews diperoleh hasil regresi OLS sebagai berikut:

Kemudian dilakukan uji asumsi klasik dan terbuti bahwa model regresi ini lolos dari uji normalitas, multikolinearitas, autokorelsi dan heterokedastisitas. Sehingga persamaannya:

$$
\begin{aligned}
\text { Y_RENDAH }= & 17.1453940301+1.26093065075 X 1- \\
& 2.06478804296 \times 2-0.142045651041 \times 3 \\
& +0.417578264638 \times 4-0.0184286191554 \times 5
\end{aligned}
$$

\section{Uji Hipotesis untuk Perusahaan dengan Growth Opportunities Rendah (Model PER Rendah)}

\section{Pengaruh secara serempak}

Berdasarkan olah data regresi OLS diatas maka dapat dapat dibuktikan secara empiris bahwa struktur kepemilikan, financial leverage, Size, dan

Tabel 1. Hasil Regresi OLS

Dependent Variable: Y_RENDAH

Method: Least Squares

Date: 06/ 02/ 15Time: 14:45

\begin{tabular}{|c|c|c|c|c|}
\hline Variable & Coefficient & Std. Error & t-Statistic & Prob. \\
\hline C & 17.14539 & 1.198487 & 14.30586 & 0.0000 \\
\hline $\mathrm{X} 1$ & 1.260931 & 1.074846 & 1.173126 & 0.2438 \\
\hline$x 2$ & -2.064788 & 1.061739 & -1.944722 & 0.0549 \\
\hline$\times 3$ & -0.142046 & 0.047340 & -3.000515 & 0.0035 \\
\hline X4 & 0.417578 & 0.174638 & 2.391108 & 0.0189 \\
\hline$\times 5$ & -0.018429 & 0.037700 & -0.488816 & 0.6262 \\
\hline R-squared & \multicolumn{2}{|c|}{0.194353 Mean dependent var } & & 13.37001 \\
\hline Adjusted R-squared & \multicolumn{2}{|c|}{0.149595 S.D. dependent var } & & 0.829641 \\
\hline S.E. of regression & \multicolumn{2}{|c|}{0.765074 A kaike info criterion } & & 2.362773 \\
\hline Sum squared resid & \multicolumn{2}{|c|}{ 52.68042 Schwarz criterion } & & 2.523044 \\
\hline Log likelihood & \multicolumn{2}{|c|}{-107.4131 H annan-Quinn criter. } & & 2.427557 \\
\hline F-statistic & \multicolumn{2}{|c|}{ 4.342294 Durbin-Watson stat } & & 1.545627 \\
\hline Prob(F-statistic) & \multicolumn{2}{|c|}{0.001382} & & \\
\hline
\end{tabular}

Sample: 196

Included observations: 96 


\section{Jurnal Keuangan dan Perbankan | KEUANGAN}

Vol. 19, N o.3, September 2015: 391-399

sales growth memiliki pengaruh secara serempak terhadap kinerja perusahaan dengan growth opportunities rendah. Hal itu ditunjukkan dengan nilai probablitas F statistik sebesar 0,0013 < dari al pha ditolerir sebesar 5\%. Dengan demikian hipotesis pertama terbukti dan model regresi OLS ini mampu untuk dianalisis lebih lanjut

\section{Pengaruh secara Parsial}

Berdasarkan olah data regresi OLS maka diperoleh hasil empiris sebagai berikut:

1). Strukturkepemilikan Insider Ownership (INSID) secara parsial tidak berpengaruh terhadap kinerja perusahaan dengan growth Opportunities rendah, yang ditunjukkan dengan nilai probabilitas $0,2438>5 \%$, sehingga hipotesis alternatif ditolak.

2). Struktur kepemilikan Institutional Ownership (INST) secara parsial berpengaruh terhadap kinerja perusahaan dengan growth Opportunities rendah, yang ditunjukkan dengan nilai probabilitas $0,054<10 \%$, sehingga hipotesis alternatif diterima.

3). Financial Leverage (LEV) secara parsial berpengaruh terhadap kinerja perusahaan dengan growth Opportunities rendah, yang ditunjukkan dengan nilai probabilitas 0,0035 $<\%$, sehingga hipotesis alternatif diterima.

4). Size (Board) secara parsial berpengaruh terhadap kinerja perusahaan dengan growth Opportunities rendah, yang ditunjukkan dengan nilai probabilitas $0,0189<5 \%$, sehingga hipotesis alternatif diterima.

5). Sales growth (SG) secara parsial berpengaruh terhadap kinerja perusahaan dengan growth Opportunities rendah, yang ditunjukkan dengan nilai probabilitas 0,6262 $>5 \%$, sehingga hipotesis alternatif ditolak.

\section{Pembahasan}

Penelitian ini dililakukan dengan tujuan untuk mengetahui dan menganalisis pengaruh Indiser
Ownership (INSID), Institutional ownership (INST), Financial Leverage (LEV), Size od Board (Size) dan Sales growth (SG) terhadap Kinerja perusahaan dengan growth opportunities rendah.

Berdasarkan analisisstatistik diperoleh hasil bahwa INSID tidak berpengaruh signifikan terhadap kinerja perusahaan dengan growth opportunities rendah, hal ini berhubungan dengan teori keagenan dimana kepemilikan insider memainkan peranan penting dalam mengurangi masalah keagenan. Untuk perusahaan dengan peluang investasi rendah maka kepemilikan insider sangat diperlukan untuk bisa mengurangi konflik keagenan, dan sangat diperlukan karena kepemilikan insider bertindak sebagai mekanisme kontrol dari perilaku manajemen perusahaan. Hasil statistik tidak signifikan, penjelasannya adalah adanya perbedaan perilaku struktur kepemilikan dalam kerangka kerja institusional yang berbeda berhubungan dengan masalah keagenan dan asimetri informasi. N amaun arah hubungan yang positif sesuai teori dimana semakin tinggi kepemilikan insider maka semakin tinggi pula kinerja perusahaan dengan peluang pertumbuhan rendah. Perusahaan dengan peluang pertumbuhan rendah cenderung sedikit memiliki konflik kepentingan, karena cenderung tidak ada perilaku manajer yang mengambil proyek investasi demi kepentingan pribadinya, sehingga konflik keagenan bisa diminimalisir apalagi ditambah pengawasan yang lebih besar dari insider, maka kepemilikan insider yang lebih besar akan berhubungan dengan kinerja yang tinggi pula. Temuan ini mendukung penelitian Reyna \& Encalada (2012), Conell \& Servaes (2007), Ambarwati,et.al, (2011).

Kepemilikan institusional (INST) memiliki pengaruh terhadap kinerja perusahaan dengan peluang pertumbuhan rendah artinya semakin besar kepemilikan institusional maka dapatmengurangi penggunaan ekuitas eksternal sehingga kinerja perusahaan semakin baik. Konsentrasi kepemilikan memang berpengaruh positif terhadap kinerja untuk 


\section{Dampak Struktur Kepemilikan, Financial Leverage, Board Director terhadap Nilai Perusahaan}

Sri Dwi Ari Ambarwati \& Rini Dwi Astuti

perusahaan dengan peluang pertumbuhan rendah karena memang di situ tidak ada pemegang saham mayoritas dan minoritas seperti yang terjadi pada perusahaan dengan peluang pertumbuhan tinggi. Rendahnya peluang pertumbuhan menyebabkan kebutuhan akan modal ekternal juga rendah sehingga masal ah keagenan bisa dihindari. Semakin tinggi kepemilikan institusional atau ekternal maka semakin besar kontrol yang bisa dilakukan, sehingga masalah keagenan bisa dikurangi dan akhirnyakinerja perusahaan semakin baik. Temuan ini mendukung penelitian Servaes (2007)

Financial leverage memiliki pengaruh signifikan terhadap kinerja perusahaan dengan peluang pertumbuhan rendah, hal ini terjadi karena perusahaan yang memiliki peluang pertumbuhan rendah biasanya kelebihan cashflow yang kemudian digunakan manajer untuk melakukan investasi pada proyek-proyek yang tidak menguntungkan. Sehingga perusahaan membutuhkan leverageyang tinggi untuk mendongkrak kinerja perusahaan dan adanya leverage tinggi maka kontrol perusahaan dibantu oleh kreditor atau lenders, sehingga masalah keagenan bisa dikurangi dan kinerja menjadi lebih baik. Hasil statistik menunjukkan arah hubungan negatif, hal ini dimungkinkan adanya penggunaan leverage yang tidak semestinya oleh manajer. Tingkat hutang tinggi namun tidak digunakan untuk proyek investasisehingga terjadi underinvestment dan akhirnya menyebabkan kinerja perusahaan menurun akibat beban tetap yang harus terus ditanggung oleh perusahaan. Temuan ini mendukung Reyna\& Encalada (2012), McConell \& Servaes (1995)

Size of board director mempunyai pengaruh signifikan terhadap kinerja perusahaan dengan peluang pertumbuhan rendah. Artinya banyaknya direktur dari luar perusahaan dapat memberikan kontrol yang obyektif terhadap perilaku manajer bagi pemilik perusahaan, dan membatasi kebebasan manajer dalam mengambil keputusan-keputusan keuangan yang tidak menguntungkan.
Sehingga banyak penelitian menemukan bukti empiris bahwa hubungan antara size of board director dan kinerja perusahaan adalah negatif. Namun riset ini menemukan hubungan yang positif signifikan, hal ini kemungkinan karenajika terlalu banyak komposisi direktur dari luar maka semakin banyak pembatasan-pembatasan yang mereka lakukan, sehingga lebih baik komposisi direktur ekternal itu lebih kecil. Sesuai dengan penelitian San Martin (2010), Reyna \& Encalada (2012) yang menemukan bukti empiris size of board berpengaruh positif signifikan terhadap kinerja. Semakin kecil sie of board semakin tinggi nilai perusahaan.

Sales of Growth mempunyai pengaruh tidak signifikan terhadap kinerja perusahaan dengan pe luang pertumbuhan rendah. Hal ini terjadi karena sedikitnya investasi yang dilakukan perusahaan menyebabkan kelebihan cashflow yang salah satunya berasal dari penjualan menyebabkan perusahaan mengalami underinvestmen sehingga nilai perusahaan tidak bisa meningkat. Tujuan perusahaan untuk memaksimumkan nilai pemegang saham tidak terwujud. Sehingga pertumbuhan penjualan tidak mempengaruhi nilai perusahaan, karena hasil penjualan tidak dimanfaatkan dengan melakukan investai pada proyek-proyek yang menguntungkan, karena memang tidak memiliki peluang investasi. Temuan ini tidak selaras dengan penelitian Abbor (2005).

\section{KESIMPULAN DAN SARAN}

\section{Kesimpulan}

Penelitian ini sudah bisa membuktikan bahwa secara empiris bahwa struktur kepemilikan, financial leverage, Size of board director, dan sales growth memiliki pengaruh secara serempak terhadap kinerja perusahaan dengan growth opportunities rendah.

Jika dilihat pengaruhnya secara parsial maka ditemukan bukti empiris bahwa variabel financial leverage dan size of board director berpengaruh 


\section{Jurnal Keuangan dan Perbankan | KEUANGAN}

Vol. 19, N 0.3, September 2015: 391-399

secara signifikan terhadap kinerja perusahaan dengan growth opportunities rendah. Untuk struktur kepemilikan institusional dinyatakan berpengaruh signifikan terhadap kinerja namun pada tingkat al pha ditolerir $10 \%$. Sedangkan Struktur kepemilikan Insider Ownership (INSID) dan Sales Growth secara parsial tidak berpengaruh terhadap kinerja perusahaan dengan growth Opportunities rendah.

\section{Saran}

Berdasarkan kesimpulan maka saran yang bisa disampaikan untuk perbaikan penelitian ini adalah sebagai berikut:

1. Perusahaan sebaiknya lebih memperhatikan financial leverage dan size of board director serta kepemilikan institusional karena ketiganya ini berpengaruh dalam meningkatkan kinerja perusahaan dengan growth opportunities rendah.

2. Bagi peneliti selanjutnya sebaiknya mencoba menggunakan periode penelitian yang lebih panjang sehingga ditemukan hasil penelitian yang lebih robust.

3. Penelitian ini memiliki keterbatasan pada data sizeof board sehingga perlu dilakukan pendekatan atau penetapan proksi yang lebih baik.

\section{DAFTAR PUSTAKA}

Abor, 2005, The Effect of Capital Structure on Profitability: An Empirical Analysis of Listed Firms in Ghana, The Journal of Risk Finance, V ol. 6, N o. 5, pp 438-445

Agarwal, R and Elston, JA 2001, 'Bank-firm relationships, financing and firm performancein Germany', Economics Letters, vol.72, pp.225-232.

Agus Harjito, 2006, Substitution Relationship between the Agency Problem Control Mechanisms in $\mathrm{Ma}$ laysia, Siasat Bisnis, p 111-117

A hmad, Abdullah and Roslan, 2012, Capital Structure Effect on Firms Performance: Focusing on Consumers and Industrials Sectors on Malaysian
Firms, International Review of Business Research $\mathrm{Pa}$ pers V ol. 8. N o.5. July 2012. Pp. 137 - 155

Brigham, E and Houston, 2006, Dasar-D asar M anajemen Keuangan, Penerbit Salemba, Edisi kesepuluh

Chen, C., \& T. Steiner. (2005). Tobin's q, managerial ownership, dan analyst coverage:A nonlinear simultaneous: A nonlinear simultaneous equations model.Journal of Economics and Business 52: 365382.

Eisenhardt, 1999, Agency Theory an Assesment and Re view, A cademy of M anagement Review, vo. 14, no. 1, pp 57-74

Gozali, 2005, A plikasi analisis M ultivariate dengan Program SPSS, Edisi ketiga, Badan Penerbit UNDIP, Semarang

Gleason KC, Mathur LK and Mathur I,2000, 'The interre lationship between cultures, capital structure, and performance: Evidence from European retailers', Journals of Business Research, vol.50, pp.185-91

Kallapur, et.al, 1999, The Asosiation Between Investment Oportunity SetProxies and Realized Growth, Journal of Business Finance and A ccounting, pp 505-519

La Porta,R,F.Lopez-de-Silanes,A.Shleifer dan R.W.Vishny.1997. Legal Determinants of External Finance. Journal of Finance.52. 1131-1150

La Porta,R,F.Lopez-de-Silanes,A.Shleifer dan R.W.Vishny.1999. Corporate Ownership Around the World. Journal of Finance.54. 471-517

La Porta,R,F.Lopez-de-Silanes,A.Shleifer dan R.W.Vishny. 2000.Investor Protection and CorporateGovernance. Journal of Financial Economics.58(12).3-27

La Porta,R,F.Lopez-de-Silanes,A.Shleifer dan R.W.Vishny. 2000. Agency Problem and Dividend Policies Around The World. Journal of Finance. 60. 1-33.

Mayer, C.,1996, Corporate Governance, competition, and performance, Jornal of Law and Society, 24, 152-76

McConnell and Servaes, H. 1995, Equity Ownership and the two faces of debt, Journal of Financial E con omics, 39, 131-57

Mesquita and Lara 2003, 'Capital structure and profitability: The Brazilian case', Working paper, A cad- 


\section{Dampak Struktur Kepemilikan, Financial Leverage, Board Director terhadap Nilai Perusahaan}

Sri Dwi Ari Ambarwati \& Rini Dwi Astuti

emy of Business and Administration Sciences Conference, Vancouver, July 11-13

Modigliani, F and Miller, M 1958, 'The cost of capital, corporation finance and the theory of investment', The A merican Economic Review, vol. 48 no. 3, pp. 261-97.

Modigliani, F and Miller, M 1963, 'Corporateincometaxes and thecost of capital: A correction', A merican Economic Review, vol. 53, pp. 443-53.

Reyna-Encalada, 2012, Ownership Structure, Firm Value and Investment Opportunity Sets: Evidence from Mexican Firm, Journal of Entrepreneurship, $M$ anagement and Innovation, V olume 8, Issue 3, pp 35-37

Riahi-Belkaouli \& Picur, 2001, Investment Opportunity Sets Dependence of Dividend Yield and PriceEarnings Ratio, $M$ anagerial Finance, V olume $27 \mathrm{~N}$ umber 3
Smith and Watts, 1992, The Investment opportunity set and corporate financing, dividend and compensation policies, Journal of Finacial Economics, 32, pp 263-292

Weston, J.Freud and Brigham, F.Eugene. 1992. D asar-dasar $M$ anajemen Keuangan. Jilid Dua. Erlangga: Jakarta.

Wilopo dan Sekar Mayangsari. 2002. Pengaruh Struktur Kepemilikan,Perilaku Manajemen Laba,Free Cash Flow Hypotesis dan Economic Value Added: Pendekatan Path Analysis.Simposium Nasional Keuangan In Memorium Prof.Dr.Bambang Riyanto.Hal:87-112. 